\title{
ORIGINAL RESEARCH \\ Clustering of Five Health-Related \\ Behaviors for Chronic Disease Prevention Among Adults, United States, 2013
}

\author{
Yong Liu, MD, MS; Janet B. Croft, PhD; Anne G. Wheaton, PhD; Dafna Kanny, PhD; \\ Timothy J. Cunningham, ScD; Hua Lu, MS; Stephen Onufrak, PhD; \\ Ann M. Malarcher, PhD; Kurt J. Greenlund, PhD; Wayne H. Giles, MD, MS
}

Suggested citation for this article: Liu Y, Croft JB, Wheaton AG, Kanny D, Cunningham TJ, Lu H, et al. Clustering of Five HealthRelated Behaviors for Chronic Disease Prevention Among Adults, United States, 2013. Prev Chronic Dis 2016;13:160054. DOI: http://dx.doi.org/10.5888/pcd13.160054.

\section{PEER REVIEWED}

\section{Abstract}

\section{Introduction}

Five key health-related behaviors for chronic disease prevention are never smoking, getting regular physical activity, consuming no alcohol or only moderate amounts, maintaining a normal body weight, and obtaining daily sufficient sleep. The objective of this study was to estimate the clustering of these 5 health-related behaviors among adults aged 21 years or older in each state and the District of Columbia and to assess geographic variation in clustering.

\section{Methods}

We used data from the 2013 Behavioral Risk Factor Surveillance System (BRFSS) to assess the clustering of the 5 behaviors among 395,343 BRFSS respondents aged 21 years or older. The 5 behaviors were defined as currently not smoking cigarettes, meeting the aerobic physical activity recommendation, consuming no alcohol or only moderate amounts, maintaining a normal body mass index (BMI), and sleeping at least 7 hours per 24-hour period. Prevalence of having 4 or 5 of these behaviors, by state, was also examined.

\section{Results}

Among US adults, $81.6 \%$ were current nonsmokers, $63.9 \%$ obtained 7 hours or more sleep per day, $63.1 \%$ reported moderate or no alcohol consumption, $50.4 \%$ met physical activity recommendations, and $32.5 \%$ had a normal BMI. Only $1.4 \%$ of respondents engaged in none of the 5 behaviors; $8.4 \%, 1$ behavior; $24.3 \%, 2$ behaviors; $35.4 \%, 3$ behaviors; and $24.3 \%$, 4 behaviors; only $6.3 \%$ reported engaging in all 5 behaviors. The highest prevalence of engaging in 4 or 5 behaviors was clustered in the Pacific and Rocky Mountain states. Lowest prevalence was in the southern states and along the Ohio River.

\section{Conclusion}

Additional efforts are needed to increase the proportion of the population that engages in all 5 health-related behaviors and to eliminate geographic variation. Collaborative efforts in health care systems, communities, work sites, and schools can promote all 5 behaviors and produce population-wide changes, especially among the socioeconomically disadvantaged.

\section{Introduction}

In 1982, the Alameda County (California) Study identified 5 key lifestyle behaviors for preventing chronic disease as being significantly associated with reduced mortality (1). The behaviors were never smoking, getting regular physical activity, drinking fewer than 5 drinks at one sitting, maintaining a normal body weight, and sleeping 7 to 8 hours per night. In 1985, the first assessment of clustering of these 5 health-related behaviors and 2 additional eating behaviors (not skipping breakfast and not snacking between meals) in the US population demonstrated disparities among racial/ethnic and socioeconomic groups (2).

Since 1985, most studies that have assessed clustering of health behaviors related to chronic disease or their impact on mortality (3-7) have not included getting sufficient sleep. The primary reason for this omission is the lack of national surveillance data on sleep duration until 2004 and lack of a formal recommendation for 
hours of sleep for adults until 2015 (8). In 2015, the American Academy of Sleep Medicine and Sleep Research Society recommended that adults should regularly get 7 or more hours of sleep nightly (8). One study found that US adults who slept 7 to 8 hours daily reported lower prevalence of cigarette smoking, drinking 5 or more servings of alcohol beverages in one day during the past year, physical inactivity, and obesity than adults who slept less than 7 hours (9). However, insufficient sleep is an independent risk factor for mortality and the development of chronic diseases after accounting for other health-related behaviors (10).

No current estimates exist of the clustering of all 5 health-related behaviors among US adults, although one recent study examined geographic variation by state of getting sufficient sleep (11). The objective of this study was to estimate the clustering of these 5 health-related behaviors among adults aged 21 years or older in 50 states and the District of Columbia and to assess geographic and sociodemographic variations in clustering.

\section{Methods}

\section{Data sources}

We used data from the 2013 Behavioral Risk Factor Surveillance System (BRFSS), an ongoing random-digit-dialed telephone survey of noninstitutionalized US adults aged 18 years or older that is conducted by state health departments with assistance from the Centers for Disease Control and Prevention. The survey sample is selected through a multistage sampling design of households with either landline or cellular telephones. Response rates for BRFSS are calculated using standards set by the American Association of Public Opinion Research Response Rate, Formula 4 (www.aapor.org/AAPOR_Main/media/publications/StandardDefinitions20169theditionfinal.pdf). The response rate is the number of respondents who completed the survey as a proportion of all eligible and likely eligible persons. The median survey response rate for all 50 states and the District of Columbia in 2013 was $45.9 \%$ and ranged from $29.0 \%$ in Alabama to $59.2 \%$ in North Dakota (www.cdc.gov/brfss/annual_data/2013/pdf/ 2013_DQR.pdf). Additional information about the 2013 BRFSS is available (www.cdc.gov/brfss/annual_data/annual_2013.html).

All 5 health-related behaviors assessed in this study are included as topics in Healthy People 2020. A normal body weight is defined as a body mass index (BMI, in $\mathrm{kg} / \mathrm{m}^{2}$ ), based on self-reported height and weight, of 18.5 to 24.9. Nondrinkers or moderate drinkers are people who drank no alcohol or drank alcohol in moderation during the past 30 days. Moderate drinking was defined as drinking up to 2 alcoholic drinks per day for men and up to 1 drink per day for women (12), no reported binge drinking
( 5 or more drinks on one occasion for men and 4 or more drinks for women), and no heavy drinking ( 15 or more drinks per week for men and 8 or more drinks per week for women during the past 30 days) (12). Engaging in aerobic physical activity was defined as self-reported aerobic physical activity in the past month of at least 150 minutes per week of moderate-intensity physical activity, 75 minutes per week of vigorous-intensity physical activity, or a combination of moderate and vigorous activity. Current nonsmoking was defined as respondents self-reporting not smoking 100 cigarettes or more during their lifetime or having smoked at least 100 cigarettes during their lifetime but not smoking at the time of the survey. Sufficient sleep was defined as reporting usually getting 7 or more hours of sleep during a 24-hour period (10).

The study population was restricted to adults of legal drinking age ( $\geq 21 \mathrm{y}$ ) who resided in one of the 50 states or the District of Columbia, excluding pregnant women and respondents who had a missing value for age or any of the 5 health-related behaviors. The final study population was 395,343 adults aged 21 years or older.

\section{Statistical analysis}

Age-adjusted weighted prevalence with 95\% confidence intervals (CIs) for the number (0-5) of health-related behaviors was calculated by state and by selected demographic characteristics by using SAS-callable SUDAAN, version 10.0.1 (Research Triangle Institute). Calculations accounted for the complex sampling design. All significant differences $(P<.05)$ between subgroups were determined by $t$ tests.

\section{Results}

The highest crude percentage of individual health-related behaviors was current nonsmoking $(81.6 \%)$, followed by sufficient sleep $(63.9 \%)$, nondrinking or moderate drinking $(63.1 \%)$, meeting recommendations for aerobic physical activity $(50.4 \%)$, and maintaining a normal BMI (32.5\%). A small proportion of respondents (1.4\%) reported none of the 5 health-related behaviors; $8.4 \%$ reported one behavior, $24.3 \%$ reported 2 behaviors, $35.4 \%$ reported 3 behaviors, $24.3 \%$ reported 4 behaviors, and only $6.3 \%$ reported all 5 behaviors (Table 1). Adults aged 65 years or older had the highest percentage $(10.1 \%)$ of all 5 health-related behaviors compared with other age groups. A higher age-adjusted percentage of all 5 health-related behaviors was observed among women (7.6\%) than men (4.8\%) and among Asian respondents (11.6\%) than all other racial/ethnic groups $(P<.001$ for both comparisons). Compared with non-Hispanic white respondents, non-Hispanic blacks, Hispanics, and American Indians/Alaska Natives $(P \leq .001$ for all comparisons) had lower age-adjusted percentages of all 5 health-

\footnotetext{
The opinions expressed by authors contributing to this journal do not necessarily reflect the opinions of the U.S. Department of Health and Human Services, the Public Health Service, the Centers for Disease Control and Prevention, or the authors' affiliated institutions.
} 
related behaviors. The age-adjusted percentage of reporting all 5 health-related behaviors increased with greater educational attainment.

The age-adjusted percentage for each number of health-related behaviors varied by state (Table 2). Utah had the highest percentage of respondents reporting all 5 health-related behaviors (11.3\%), and 7 states (Arkansas, Louisiana, Mississippi, North Dakota, Rhode Island, Tennessee, and Wisconsin) had percentages below $5.0 \%$.

Because a small proportion of respondents reported all 5 health-related behaviors, we compared those reporting 4 or 5 health-related behaviors (30.2\% age-adjusted overall) by sex and racial/ethnic group (Figure 1) and by state (Figure 2). A significantly higher percentage of women reported 4 or 5 health-related behaviors than men in all racial/ethnic groups except for non-Hispanic blacks (Figure 1). Lower age-adjusted percentages of respondents reporting 4 or 5 health-related behaviors clustered in many southern states and among states along the Ohio River, whereas higher percentages clustered in the Pacific and Rocky Mountain states (Figure 2).

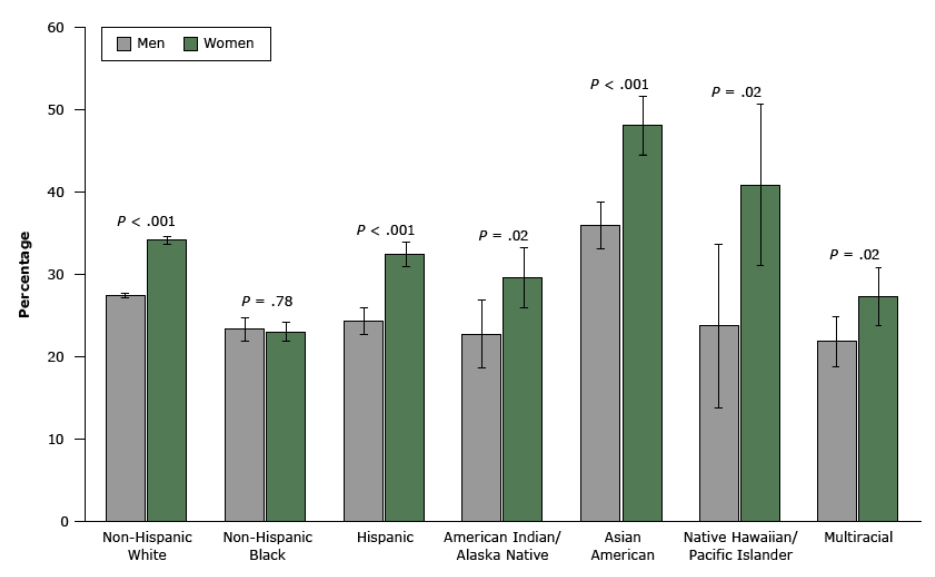

Figure 1. Age-adjusted prevalence of engaging in 4 or 5 health-related behaviors among adults aged 21 years or older, Behavioral Risk Factor Surveillance System, 2013. Error bars indicate 95\% confidence intervals.

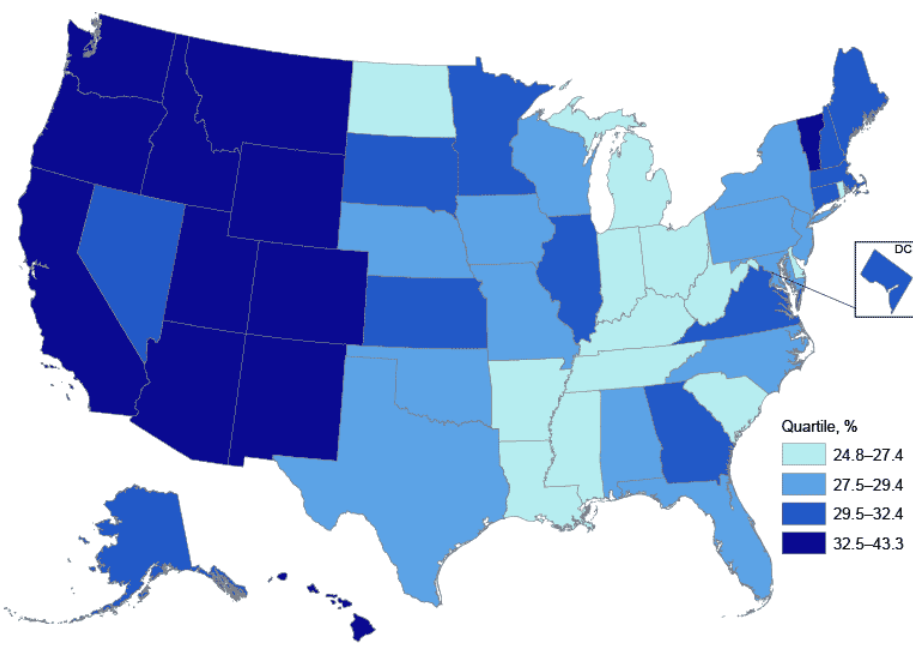

Figure 2. Age-adjusted prevalence of adults aged 21 years or older selfreporting 4 or 5 health-related behaviors, by state and quartile, Behavioral Risk Factor Surveillance System, 2013.

\section{Discussion}

This study is the first to describe distributions of the 5 health-related behaviors, including sufficient sleep, related to Healthy People 2020 objectives since the Alameda County Study of 1982, which demonstrated lower mortality risk among adults with these behaviors and disparities among racial/ethnic and socioeconomic groups (2). Our results confirmed that these disparities persisted after 3 decades. Women, older respondents ( $\geq 65 \mathrm{y}$ ), college graduates, and Asians were more likely to engage in 5 health-related behaviors than men, and other age, education, and racial/ethnic groups. We also found that most US adults did not meet recommendations for aerobic physical activity or did not have a normal BMI. Overall, only $6.3 \%$ of the adult population reported engaging in all 5 health-related behaviors in 2013. Although state variations in prevalence of smoking, obesity, physical inactivity, and binge drinking or heavy drinking were mapped separately (www.cdc.gov/brfss/), this is the first geographic assessment of the clustering of these health-related behaviors. This study demonstrates a higher percentage of 5 health-related behaviors in the Pacific and Rocky Mountain states than in southern states.

The lower percentage of people engaging in 4 or more health-related behaviors in the states bordering the Ohio River and southern states compared with other states is consistent with, and indirectly reflects, geographic variations in mortality rates and Medicare hospitalization rates for heart disease and stroke (www.cdc.gov/dhdsp/maps/national_maps) in these states and a high prevalence of chronic obstructive pulmonary disease and dia-

\footnotetext{
The opinions expressed by authors contributing to this journal do not necessarily reflect the opinions of the U.S. Department of Health and Human Services, the Public Health Service, the Centers for Disease Control and Prevention, or the authors' affiliated institutions.
} 
betes (13-16). Geographic variation and racial/ethnic disparity among respondents reporting 4 or more health-related behaviors reinforce the need for integrated, comprehensive strategies that address all of these behaviors to create sustained population-wide changes; special attention is needed for socioeconomically disadvantaged populations (17).

Our study has several limitations. First, all health-related behaviors are self-reported and subject to reporting bias. Second, BRFSS is a household telephone survey that does not include people living in institutions, long-term care facilities, and prisons; therefore, our results cannot be extrapolated to those groups. Third, because state response rates were relatively low, nonresponse to the telephone survey may have affected results. Fourth, moderate alcohol use was included as a health-related behavior to help reduce the risk of alcohol-attributable harms among current adult drinkers (12), and not to promote the potential health benefit of moderate drinking, which emerging scientific evidence may not support (18). The US Dietary Guidelines also does not recommend that individuals who do not drink alcohol start drinking for any reason (12). Finally, only respondents who provided responses to questions about all 5 health-related behaviors were included in the study. Rates of exclusion from the study were higher among young adults, Hispanics, Native Hawaiians/Pacific Islanders, women, and adults with less education than a high school diploma; these exclusions could have resulted in underestimates or overestimates of health-related behaviors in those groups. However, state variation in exclusions did not follow any pattern that would appear to affect the geographic clustering of health-related behaviors.

Although each health-related behavior has a Healthy People 2020 objective, the 5 behaviors we examined are probably not equal in their health consequences or their amenability to intervention. Therefore, multiple strategies should be employed for the 5 behaviors examined through various avenues that focus on changes in individual behavior and on environmental, policy, and systems changes; we provide examples of such strategies (19-29) (Table 3 ). First, these strategy examples require linkages with partners in disciplines other than public health as well as stronger linkages between public health and health care than currently exist. Second, although we did not examine children and adolescents in this analysis, health-related behaviors begin in childhood and may be associated with a lower risk of chronic disease in adulthood (30); therefore, strategies to promote health-related behaviors among adults must also include attention to strategies that address children, such as those in early care and education and in school settings. Third, evidence-based environmental approaches in communities, work sites, and schools include providing access to facilities and opportunities to promote lifestyle changes and promoting policies that support and reinforce health practices. In addition, health care system policies can ensure that health care providers assess these key behaviors in office visits and counsel all patients to practice all 5 health-related behaviors. Finally, community-clinical linkages may involve health care providers referring patients with chronic diseases to community-based lifestyle intervention programs and including risk factor reduction via these 5 health-related behaviors in chronic disease self-management programs. These efforts in both the public health sector and health care systems could place a greater emphasis on the promotion of health-related behaviors that prevent chronic diseases and have the potential to support an improved quality of life, reduce development of chronic conditions, reduce demand on the health care system, and improve overall population health (17).

Additional efforts are needed to increase the proportion of the population who engage in all 5 health-related behaviors addressed in this study. Collaborative efforts among public health agencies, health care systems, community coalitions, work sites, early child care and education, and schools can provide opportunities and support policies that promote these 5 behaviors and create population-wide changes, especially changes in racial/ethnic minority populations and socioeconomically disadvantaged populations. Coordinated, comprehensive approaches in clinical and public health sectors that address multiple behaviors or risk factors may allow more efficient leveraging of resources and increase the impact of interventions.

\section{Acknowledgments}

This research received no specific grant from any funding agency in the public, commercial, or nonprofit sectors. The findings and conclusions of this report are those of the authors and do not necessarily represent the official position of the Centers for Disease Control and Prevention.

\section{Author Information}

Corresponding Author: Yong Liu, MD, MS, Division of Population Health, National Center for Chronic Disease Prevention and Health Promotion, 4770 Buford Hwy, MS F-78, Atlanta, GA 30341.Telephone: 770-488-5528. Email: ikd8@cdc.gov.

Author Affiliations: Janet B. Croft, Anne G. Wheaton, Dafna Kanny, Timothy J. Cunningham, Hua Lu, Stephen Onufrak, Ann M. Malarcher, Kurt J. Greenlund, Wayne H. Giles, National Center for Chronic Disease Prevention and Health Promotion, Centers for Disease Control and Prevention, Atlanta, Georgia.

The opinions expressed by authors contributing to this journal do not necessarily reflect the opinions of the U.S. Department of Health and Human Services, the Public Health Service, the Centers for Disease Control and Prevention, or the authors' affiliated institutions. 


\section{References}

1. Wingard DL, Berkman LF, Brand RJ. A multivariate analysis of health-related practices: a nine-year mortality follow-up of the Alameda County Study. Am J Epidemiol 1982; 116(5):765-75.

2. Schoenborn CA. Health habits of US adults, 1985: the "Alameda 7" revisited. Public Health Rep 1986; 101(6):571-80.

3. McGinnis JM, Foege WH. Actual causes of death in the United States. JAMA 1993;270(18):2207-12.

4. Stampfer MJ, Hu FB, Manson JE, Rimm EB, Willett WC. Primary prevention of coronary heart disease in women through diet and lifestyle. N Engl J Med 2000;343(1):16-22.

5. Mokdad AH, Marks JS, Stroup DF, Gerberding JL. Actual causes of death in the United States, 2000.[Published erratum in: JAMA 2005;293(3):298]. JAMA 2004;291(10):1238-45.

6. Ford ES, Zhao G, Tsai J, Li C. Low-risk lifestyle behaviors and all-cause mortality: findings from the National Health and Nutrition Examination Survey III Mortality Study. Am J Public Health 2011;101(10):1922-9.

7. Lloyd-Jones DM, Hong Y, Labarthe D, Mozaffarian D, Appel LJ, Van Horn L, et al. Defining and setting national goals for cardiovascular health promotion and disease reduction: the American Heart Association's Strategic Impact Goal through 2020 and beyond. Circulation 2010;121(4):586-613.

8. Watson NF, Badr MS, Belenky G, Bliwise DL, Buxton OM, Buysse D, et al. Recommended amount of sleep for a healthy adult: a joint consensus statement of the American Academy of Sleep Medicine and Sleep Research Society. Sleep 2015; 38(6):843-4.

9. Schoenborn CA, Adams PF. Sleep duration as a correlate of smoking, alcohol use, leisure-time physical inactivity, and obesity among adults: United States, 2004-2006. NCHS Health E-Stats. Hyattsville (MD): National Center for Health Statistics; 2008. http:/www.cdc.gov/nchs/data/hestat/sleep0406/sleep04-06.htm. Accessed March 2, 2015.

10. Watson NF, Badr MS, Belenky G, Bliwise DL, Buxton OM, Buysse D, et al. Joint consensus statement of the American Academy of Sleep Medicine and Sleep Research Society on the recommended amount of sleep for a healthy adult: methodology and discussion. Sleep 2015;38(8):1161-83.

11. Liu Y, Wheaton AG, Chapman DP, Cunningham TJ, Lu H, Croft JB, et al. Prevalence of healthy sleep duration among adults — United States, 2014. MMWR Morb Mortal Wkly Rep 2016;65(6):137-41.
12. US Department of Health and Human Services and US Department of Agriculture. 2015-2020 Dietary guidelines for Americans. 8th Edition. Washington (DC): US Government Printing Office; 2015.

13. Casper M, Nwaise I, Croft JB, Hong Y, Fang J, Greer S. Geographic disparities in heart failure hospitalization rates among Medicare beneficiaries. J Am Coll Cardiol 2010; 55(4):294-9.

14. Barker LE, Kirtland KA, Gregg EW, Geiss LS, Thompson TJ. Geographic distribution of diagnosed diabetes in the US: a diabetes belt. Am J Prev Med 2011;40(4):434-9.

15. Ford ES, Croft JB, Mannino DM, Wheaton AG, Zhang X, Giles WH. COPD surveillance — United States, 1999-2011. Chest 2013;144(1):284-305.

16. Casper M, Kramer MR, Quick H, Schieb LJ, Vaughan AS, Greer S. Changes in the geographic patterns of heart disease mortality in the United States: 1973 to 2010. Circulation 2016; 133(12):1171-80.

17. Bauer UE, Briss PA, Goodman RA, Bowman BA. Prevention of chronic disease in the 21st century: elimination of the leading preventable causes of premature death and disability in the USA. Lancet 2014;384(9937):45-52.

18. Andreasson S, Chlkritzhs T, Dangardt F, Holder H, Naimi T, Stockwell T. Evidence about health effects of "moderate" alcohol consumption: reasons for skepticism and public health implications. In: Alcohol and Society 2014. Stockholm (SE): IOGT-NTO and Swedish Society of Medicine. http://iogt.se/ wp - content/uploads/A1koholrapp-2014_ENG s\%C3\%A4rtryck.pdf. Accessed November 3, 2015.

19. Centers for Disease Control and Prevention. Best practices for comprehensive tobacco control programs - 2014. Atlanta (GA): US Department of Health and Human Services, Centers for Disease Control and Prevention, National Center for Chronic Disease Prevention and Health Promotion, Office on Smoking and Health; 2014. http://www.cdc.gov/tobacco/ stateandcommunity/best_practices/pdfs/2014/ comprehensive.pdf. Accessed March 2, 2015.

20. Keener D, Goodman K, Lowry A, Zaro S, Kettel Khan L. Recommended community strategies and measurements to prevent obesity in the United States: implementation and measurement guide. Atlanta (GA): US Department of Health and Human Services, Centers for Disease Control and Prevention; 2009. http://www.cdc.gov/obesity/downloads/ community_strategies_guide.pdf. Accessed March 2, 2015.

21. Task Force on Community Preventive Services. A recommendation to improve employee weight status through worksite health promotion programs targeting nutrition, physical activity, or both. Am J Prev Med 2009;37(4):358-9.

The opinions expressed by authors contributing to this journal do not necessarily reflect the opinions of the U.S. Department of Health and Human Services, the Public Health Service, the Centers for Disease Control and Prevention, or the authors' affiliated institutions. 
22. Thompson PD, Buchner D, Piña IL, Balady GJ, Williams MA, Marcus BH, et al. Exercise and physical activity in the prevention and treatment of atherosclerotic cardiovascular disease: a statement from the Council on Clinical Cardiology (Subcommittee on Exercise, Rehabilitation, and Prevention) and the Council on Nutrition, Physical Activity, and Metabolism (Subcommittee on Physical Activity). Circulation 2003;107(24):3109-16.

23. Task Force on Community Prevention Services. Preventing excessive alcohol consumption. In: The guide to community preventive services. New York (NY): Oxford University Press; 2005. http://www.thecommunityguide.org/alcohol/index.html. Accessed November 3, 2015.

24. Moyer VA;Preventive Services Task Force. Screening and behavioral counseling interventions in primary care to reduce alcohol misuse: US Preventive Services Task Force recommendation statement. Ann Intern Med 2013; 159(3):210-8.

25. Adolescent Sleep Working Group,Committee on Adolescence, Council on School Health. School start times for adolescents. Pediatrics 2014;134(3):642-9.

26. Wheaton AG, Chapman DP, Croft JB. School start times, sleep, behavior, health, and academic outcomes: a review of the literature. J Sch Health 2016;86(5):363-81.

27. Mukherjee S, Patel SR, Kales SN, Ayas NT, Strohl KP, Gozal D, et al. An official American Thoracic Society statement: the importance of healthy sleep: recommendations and future priorities. Am J Respir Crit Care Med 2015;191(12):1450-8.

28. Lerman SE, Eskin E, Flower DJ, George EC, Gerson B, Hartenbaum N, et al. Fatigue risk management in the workplace. J Occup Environ Med 2012;54(2):231-58.

29. Chung F, Yegneswaran B, Liao P, Chung SA, Vairavanathan S, Islam S, et al. STOP questionnaire: a tool to screen patients for obstructive sleep apnea. Anesthesiology 2008; 108(5):812-21.

30. Laitinen TT, Pahkala K, Magnussen CG, Viikari JS, Oikonen $\mathrm{M}$, Taittonen L, et al. Ideal cardiovascular health in childhood and cardiometabolic outcomes in adulthood: the Cardiovascular Risk in Young Finns Study. Circulation 2012; 125(16):1971-8.

\footnotetext{
The opinions expressed by authors contributing to this journal do not necessarily reflect the opinions of the U.S. Department of Health and Human Services, the Public Health Service, the Centers for Disease Control and Prevention, or the authors' affiliated institutions.
} 


\section{Tables}

Table 1. Age-Specific and Age-Adjusted Percentage ${ }^{a}$ of Adults Aged $\geq 21$ Years Reporting Health-Related Behaviors, by Selected Characteristics, Behavioral Risk Factor Surveillance System, United States, 2013

\begin{tabular}{|c|c|c|c|c|c|c|c|}
\hline \multirow[b]{2}{*}{ Characteristic } & \multirow{2}{*}{$\begin{array}{l}\text { No. of Survey } \\
\text { Respondents }\end{array}$} & \multicolumn{6}{|c|}{ Weighted \% $(95 \% \mathrm{Cl})$, by No. of Behaviors Reported } \\
\hline & & 0 & 1 & 2 & 3 & 4 & 5 \\
\hline Total, crude & 395,343 & $1.4(1.3-1.5)$ & $8.4(8.2-8.6)$ & $24.3(24.0-24.6)$ & $35.4(35.1-35.7)$ & $24.3(24.0-24.5)$ & $6.3(6.1-6.4)$ \\
\hline Total, age-adjusted & 395,343 & $1.5(1.4-1.6)$ & $8.7(8.5-8.9)$ & $24.5(24.2-24.8)$ & $35.2(34.9-35.5)$ & $24.0(23.7-24.3)$ & $6.2(6.0-6.3)$ \\
\hline \multicolumn{8}{|l|}{ Age, $y$} \\
\hline $21-24$ & 12,944 & $2.2(1.8-2.7)$ & $9.5(8.7-10.3)$ & $24.2(23.0-25.4)$ & $32.8(31.5-34.2)$ & $24.9(23.7-26.1)$ & $6.4(5.6-7.1)$ \\
\hline $25-34$ & 39,546 & $2.0(1.8-2.3)$ & $11.2(10.7-11.7)$ & $27.2(26.4-28.0)$ & $34.1(33.3-35.0)$ & $20.3(19.6-21.0)$ & $5.2(4.8-5.6)$ \\
\hline $35-44$ & 49,106 & $1.8(1.6-2.0)$ & $10.1(9.6-10.6)$ & $26.1(25.3-26.8)$ & $34.9(34.1-35.7)$ & $21.9(21.2-22.7)$ & $5.2(4.8-5.5)$ \\
\hline $45-54$ & 70,152 & $1.7(1.5-1.9)$ & $10.3(9.8-10.7)$ & $27.2(26.5-27.9)$ & $34.4(33.7-35.1)$ & $21.5(20.9-22.1)$ & $5.0(4.6-5.3)$ \\
\hline $55-64$ & 90,411 & $1.0(0.8-1.1)$ & $7.8(7.4-8.1)$ & $24.6(24.0-25.2)$ & $36.8(36.1-37.5)$ & $24.3(23.7-24.9)$ & $5.6(5.3-5.8)$ \\
\hline$\geq 65$ & 133,184 & $0.2(0.2-0.3)$ & $2.9(2.7-3.1)$ & $17.2(16.7-17.6)$ & $37.5(36.9-38.0)$ & $32.1(31.6-32.6)$ & $10.1(9.8-10.4)$ \\
\hline \multicolumn{8}{|l|}{ Sex } \\
\hline Men & 166,193 & $1.7(1.6-1.9)$ & $9.9(9.6-10.2)$ & $26.3(25.8-26.7)$ & $35.0(34.5-35.5)$ & $22.3(21.9-22.7)$ & $4.8(4.6-5.0)$ \\
\hline Women & 229,150 & $1.2(1.1-1.3)$ & $7.4(7.1-7.6)$ & $22.7(22.3-23.1)$ & $35.4(35.0-35.9)$ & $25.7(25.3-26.2)$ & $7.6(7.3-7.8)$ \\
\hline \multicolumn{8}{|l|}{ Race/ethnicity } \\
\hline White, non-Hispanic & 314,964 & $1.4(1.3-1.5)$ & $8.8(8.5-9.0)$ & $24.2(23.9-24.5)$ & $34.9(34.6-35.3)$ & $24.2(23.9-24.6)$ & $6.4(6.3-6.6)$ \\
\hline Black, non-Hispanic & 29,901 & $2.2(1.8-2.5)$ & $11.1(10.4-11.7)$ & $28.0(27.0-28.9)$ & $35.7(34.6-36.8)$ & $19.7(18.8-20.6)$ & $3.5(3.1-3.8)$ \\
\hline Hispanic & 22,379 & $1.3(1.1-1.6)$ & $7.6(7.0-8.2)$ & $26.4(25.3-27.6)$ & $36.4(35.2-37.6)$ & $23.3(22.2-24.4)$ & $4.9(4.4-5.5)$ \\
\hline American Indian/Alaska Native & 5,990 & $2.0(1.2-2.8)$ & $12.1(10.3-13.9)$ & $27.9(25.3-30.5)$ & $32.2(29.6-34.8)$ & $21.4(18.7-24.1)$ & $4.4(3.3-5.6)$ \\
\hline Asian & 6,935 & $0.6(0.3-0.9)$ & $4.3(3.4-5.2)$ & $17.9(15.7-20.1)$ & $35.3(32.9-37.6)$ & $30.4(28.3-32.5)$ & $11.6(10.0-13.1)$ \\
\hline Native Hawaiian/Pacific Islander & 654 & $1.3(0.3-2.3)^{c}$ & $16.5(9.7-23.3)$ & $22.3(16.7-27.8)$ & $26.5(20.5-32.5)$ & $27.7(20.6-34.9)$ & $5.7(2.7-8.8)$ \\
\hline Multiracial, non-Hispanic & 7,243 & $2.0(1.2-2.8)$ & $12.0(10.0-14.1)$ & $25.9(23.6-28.2)$ & $35.6(32.9-38.3)$ & $19.4(17.3-21.5)$ & $5.1(3.8-6.4)$ \\
\hline \multicolumn{8}{|l|}{ Education } \\
\hline Less than high school graduate & 29,648 & $2.3(1.9-2.7)$ & $11.9(11.2-12.7)$ & $29.1(28.0-30.2)$ & $34.6(33.4-35.9)$ & $18.7(17.7-19.6)$ & $3.4(2.9-3.8)$ \\
\hline High school graduate or GED & 110,984 & $2.1(1.9-2.2)$ & $10.9(10.4-11.3)$ & $26.7(26.1-27.3)$ & $34.5(33.9-35.1)$ & $21.0(20.4-21.5)$ & $4.9(4.6-5.2)$ \\
\hline Some college & 108,707 & $1.6(1.5-1.8)$ & $9.1(8.8-9.5)$ & $25.3(24.7-25.8)$ & $35.1(34.5-35.7)$ & $22.9(22.4-23.5)$ & $5.9(5.6-6.2)$ \\
\hline College graduate & 145,521 & $0.5(0.4-0.5)$ & $4.9(4.7-5.1)$ & $19.6(19.2-20.0)$ & $35.8(35.3-36.3)$ & $30.3(29.8-30.8)$ & $8.9(8.6-9.1)$ \\
\hline
\end{tabular}

Abbreviations: $\mathrm{Cl}$, confidence interval, GED, general educational development.

${ }^{a}$ Age-adjusted to the 2000 projected US population, except for age groups.

${ }^{\mathrm{b}}$ Unweighted sample of respondents. Categories might not sum to survey total because of respondents with missing data on characteristics.

${ }^{c}$ Estimates are unreliable because relative standard error $>0.3$ or $n<50$. 
Table 2. Age-Adjusted Percentage ${ }^{a}$ of Adults Aged $\geq 21$ Years Reporting Health-Related Behaviors, by State, Behavioral Risk Factor Surveillance System, United States, 2013

\begin{tabular}{|c|c|c|c|c|c|c|c|}
\hline \multirow[b]{2}{*}{ State } & \multirow[b]{2}{*}{ No. ${ }^{b}$} & \multicolumn{6}{|c|}{ Weighted \% ( $95 \% \mathrm{Cl})$, by No. of Behaviors Reported } \\
\hline & & 0 & 1 & 2 & 3 & 4 & 5 \\
\hline Alabama & 5,411 & $1.0(0.6-1.4)$ & $8.4(7.3-9.6)$ & $26.5(24.5-28.4)$ & $35.5(33.5-37.5)$ & $23.2(21.5-24.9)$ & $5.4(4.5-6.3)$ \\
\hline Alaska & 3,792 & $2.0(1.2-2.8)$ & $9.8(8.2-11.3)$ & $24.6(22.6-26.6)$ & $34.0(31.8-36.1)$ & $23.6(21.7-25.4)$ & $6.1(5.0-7.1)$ \\
\hline Arizona & 3,430 & $0.8(0.4-1.1)$ & $8.0(6.2-9.9)$ & $22.9(20.1-25.6)$ & $34.8(31.8-37.8)$ & $26.7(24.1-29.4)$ & $6.8(5.5-8.1)$ \\
\hline Arkansas & 4,273 & $2.3(1.5-3.1)$ & $10.6(9.0-12.2)$ & $27.3(25.2-29.5)$ & $34.7(32.5-36.9)$ & $20.9(19.1-22.7)$ & $4.2(3.4-4.9)$ \\
\hline California & 8,893 & $0.9(0.6-1.1)$ & $6.3(5.6-7.1)$ & $21.5(20.2-22.8)$ & $35.5(34.1-37.0)$ & $27.8(26.5-29.1)$ & $7.9(7.1-8.7)$ \\
\hline Colorado & 11,043 & $1.1(0.8-1.5)$ & $6.6(5.9-7.3)$ & $19.5(18.4-20.5)$ & $34.6(33.4-35.8)$ & $29.8(28.7-30.9)$ & $8.4(7.8-9.1)$ \\
\hline Connecticut & 6,351 & $1.7(1.1-2.3)$ & $9.5(8.3-10.7)$ & $24.7(23.0-26.4)$ & $33.7(31.9-35.6)$ & $23.8(22.2-25.4)$ & $6.5(5.6-7.4)$ \\
\hline Delaware & 4,327 & $1.5(1.0-2.0)$ & $8.6(7.3-9.9)$ & $27.4(25.3-29.4)$ & $35.5(33.4-37.6)$ & $21.5(19.7-23.2)$ & $5.6(4.5-6.7)$ \\
\hline District of Columbia & 3,927 & $1.9(1.0-2.9)$ & $7.9(6.5-9.4)$ & $20.7(18.7-22.7)$ & $37.0(34.6-39.4)$ & $26.2(24.1-28.3)$ & $6.2(5.2-7.2)$ \\
\hline Florida & 26,727 & $1.1(0.8-1.3)$ & $8.3(7.4-9.2)$ & $25.2(23.8-26.6)$ & $36.4(34.9-38.0)$ & $23.4(22.1-24.7)$ & $5.5(4.8-6.3)$ \\
\hline Georgia & 6,488 & $1.5(1.0-1.9)$ & $8.9(7.9-10.0)$ & $24.1(22.6-25.6)$ & $35.0(33.4-36.7)$ & $24.4(23.0-25.9)$ & $6.0(5.3-6.7)$ \\
\hline Hawaii & 6,775 & $1.0(0.6-1.5)$ & $6.3(5.3-7.2)$ & $21.3(19.7-22.8)$ & $35.1(33.3-36.8)$ & $27.1(25.5-28.7)$ & $9.2(8.2-10.3)$ \\
\hline Idaho & 4,651 & $2.3(1.3-3.3)$ & $7.3(6.1-8.5)$ & $20.3(18.6-22.1)$ & $35.5(33.4-37.7)$ & $25.9(24.1-27.7)$ & $8.6(7.4-9.9)$ \\
\hline Illinois & 4,981 & $1.4(0.9-1.9)$ & $8.2(7.0-9.4)$ & $26.1(24.2-28.0)$ & $34.8(32.8-36.8)$ & $23.5(21.7-25.2)$ & $6.0(5.1-7.0)$ \\
\hline Indiana & 8,357 & $1.5(1.1-1.9)$ & $11.1(10.1-12.2)$ & $26.2(24.8-27.6)$ & $35.0(33.6-36.5)$ & $21.1(19.9-22.3)$ & $5.0(4.5-5.5)$ \\
\hline lowa & 6,845 & $1.8(1.2-2.3)$ & $10.8(9.6-12.0)$ & $25.0(23.5-26.5)$ & $34.6(33.0-36.2)$ & $22.4(21.0-23.7)$ & $5.5(4.8-6.1)$ \\
\hline Kansas & 19,438 & $1.3(1.0-1.5)$ & $8.2(7.7-8.8)$ & $23.5(22.7-24.3)$ & $35.4(34.5-36.3)$ & $25.4(24.6-26.2)$ & $6.2(5.8-6.6)$ \\
\hline Kentucky & 8,967 & $1.5(1.1-2.0)$ & $10.7(9.6-11.9)$ & $27.1(25.6-28.7)$ & $34.9(33.3-36.6)$ & $20.6(19.3-21.9)$ & $5.0(4.3-5.7)$ \\
\hline Louisiana & 4,332 & $2.0(1.1-2.9)$ & $9.9(8.3-11.6)$ & $27.4(25.0-29.8)$ & $34.8(32.5-37.2)$ & $21.0(19.0-23.0)$ & $4.8(3.9-5.8)$ \\
\hline Maine & 6,922 & $1.6(1.0-2.2)$ & $8.3(7.3-9.4)$ & $26.2(24.6-27.8)$ & $34.0(32.3-35.6)$ & $23.7(22.3-25.1)$ & $6.2(5.4-6.9)$ \\
\hline Maryland & 10,145 & $1.2(0.8-1.5)$ & $8.9(7.9-10.0)$ & $25.7(24.2-27.1)$ & $35.0(33.5-36.5)$ & $23.3(22.0-24.7)$ & $5.9(5.1-6.6)$ \\
\hline Massachusetts & 11,900 & $1.3(0.9-1.8)$ & $8.0(7.1-8.8)$ & $24.6(23.2-25.9)$ & $34.8(33.4-36.2)$ & $24.3(23.1-25.5)$ & $7.0(6.4-7.7)$ \\
\hline Michigan & 10,887 & $2.0(1.6-2.4)$ & $9.8(8.8-10.7)$ & $27.0(25.7-28.3)$ & $33.9(32.6-35.2)$ & $21.8(20.6-22.9)$ & $5.6(5.0-6.2)$ \\
\hline Minnesota & 11,827 & $1.7(1.2-2.2)$ & $9.4(8.4-10.4)$ & $24.3(22.8-25.8)$ & $33.9(32.3-35.5)$ & $23.8(22.4-25.3)$ & $6.9(6.0-7.7)$ \\
\hline Mississippi & 6,025 & $1.6(1.0-2.1)$ & $10.7(9.4-12.0)$ & $27.4(25.6-29.2)$ & $34.6(32.8-36.4)$ & $21.5(19.9-23.1)$ & $4.3(3.4-5.1)$ \\
\hline Missouri & 5,999 & $1.9(1.0-2.8)$ & $8.5(7.4-9.7)$ & $23.8(22.1-25.6)$ & $36.3(34.4-38.3)$ & $23.6(22.0-25.2)$ & $5.8(5.0-6.7)$ \\
\hline Montana & 8,317 & $1.0(0.7-1.3)$ & $8.7(7.7-9.6)$ & $22.3(21.0-23.6)$ & $34.3(32.7-35.8)$ & $26.5(25.0-27.9)$ & $7.3(6.5-8.1)$ \\
\hline Nebraska & 14,585 & $1.8(1.3-2.2)$ & $9.9(8.9-10.8)$ & $24.3(23.1-25.5)$ & $36.0(34.6-37.4)$ & $22.6(21.4-23.7)$ & $5.5(4.9-6.0)$ \\
\hline Nevada & 4,250 & $1.3(0.8-1.9)$ & $7.8(6.3-9.3)$ & $24.8(22.3-27.3)$ & $35.9(33.0-38.8)$ & $24.5(22.0-26.9)$ & $5.8(4.6-6.9)$ \\
\hline New Hampshire & 5,314 & $1.4(0.9-1.9)$ & $7.8(6.7-8.9)$ & $23.4(21.7-25.2)$ & $36.3(34.4-38.3)$ & $24.2(22.6-25.8)$ & $6.8(5.8-7.8)$ \\
\hline New Jersey & 10,313 & $1.4(1.0-1.8)$ & $8.7(7.8-9.6)$ & $24.7(23.4-26.0)$ & $36.5(35.0-38.0)$ & $23.0(21.7-24.3)$ & $5.7(5.0-6.3)$ \\
\hline New Mexico & 7,625 & $1.3(0.9-1.7)$ & $7.0(6.1-7.8)$ & $22.4(20.9-23.9)$ & $33.6(31.9-35.2)$ & $27.7(26.1-29.3)$ & $8.1(7.2-9.0)$ \\
\hline New York & 6,991 & $1.6(1.1-2.1)$ & $8.7(7.7-9.7)$ & $26.2(24.8-27.7)$ & $35.3(33.8-36.9)$ & $22.4(21.1-23.6)$ & $5.7(5.0-6.4)$ \\
\hline North Carolina & 7,143 & $1.2(0.8-1.5)$ & $8.7(7.7-9.7)$ & $24.3(22.9-25.8)$ & $36.4(34.8-38.0)$ & $22.8(21.5-24.2)$ & $6.6(5.8-7.3)$ \\
\hline North Dakota & 6,479 & $1.7(1.2-2.2)$ & $11.2(10.0-12.5)$ & $27.5(25.8-29.1)$ & $34.9(33.2-36.6)$ & $20.6(19.2-22.0)$ & $4.2(3.5-4.8)$ \\
\hline
\end{tabular}

Abbreviations: $\mathrm{Cl}$, confidence interval; NA, not applicable.

${ }^{\text {a }}$ Age-adjusted to the 2000 projected US population.

${ }^{\mathrm{b}}$ Unweighted sample of respondents. 
(continued)

Table 2. Age-Adjusted Percentage ${ }^{a}$ of Adults Aged $\geq 21$ Years Reporting Health-Related Behaviors, by State, Behavioral Risk Factor Surveillance System, United States, 2013

\begin{tabular}{|c|c|c|c|c|c|c|c|}
\hline \multirow[b]{2}{*}{ State } & \multirow[b]{2}{*}{ No. ${ }^{b}$} & \multicolumn{6}{|c|}{ Weighted \% (95\% Cl), by No. of Behaviors Reported } \\
\hline & & 0 & 1 & 2 & 3 & 4 & 5 \\
\hline Ohio & 9,797 & $2.3(1.7-2.9)$ & $10.4(9.4-11.3)$ & $27.3(25.9-28.7)$ & $33.4(31.9-34.9)$ & $21.1(19.9-22.3)$ & $5.5(4.8-6.2)$ \\
\hline Oklahoma & 7,025 & $1.8(1.3-2.3)$ & $10.1(9.1-11.2)$ & $25.1(23.6-26.5)$ & $34.9(33.4-36.4)$ & $22.7(21.4-24.0)$ & $5.4(4.8-6.1)$ \\
\hline Oregon & 4,744 & $1.0(0.5-1.5)$ & $6.3(5.2-7.5)$ & $20.2(18.6-21.9)$ & $34.2(32.3-36.1)$ & $29.2(27.4-31.0)$ & $9.0(7.9-10.1)$ \\
\hline Pennsylvania & 9,182 & $2.5(1.9-3.0)$ & $10.9(9.9-11.9)$ & $24.8(23.5-26.1)$ & $34.1(32.7-35.5)$ & $22.3(21.1-23.6)$ & $5.4(4.8-6.1)$ \\
\hline Rhode Island & 5,226 & $1.7(1.1-2.3)$ & $10.5(9.2-11.8)$ & $26.6(24.8-28.3)$ & $34.9(33.0-36.8)$ & $21.7(20.1-23.3)$ & $4.7(4.0-5.4)$ \\
\hline South Carolina & 8,788 & $1.8(1.3-2.2)$ & $10.0(8.9-11.0)$ & $24.7(23.3-26.1)$ & $36.3(34.7-37.8)$ & $22.2(20.9-23.5)$ & $5.1(4.4-5.7)$ \\
\hline South Dakota & 5,842 & $1.6(0.9-2.2)$ & $8.3(6.9-9.6)$ & $22.9(21.0-24.9)$ & $35.5(33.3-37.8)$ & $26.1(24.2-28.1)$ & $5.6(4.6-6.5)$ \\
\hline Tennessee & 4,510 & $1.5(0.9-2.0)$ & $10.5(9.1-12.0)$ & $26.2(24.2-28.2)$ & $36.2(34.1-38.3)$ & $21.2(19.5-23.0)$ & $4.3(3.6-5.1)$ \\
\hline Texas & 8,459 & $1.8(1.3-2.2)$ & $8.6(7.7-9.6)$ & $24.4(22.9-25.9)$ & $36.2(34.6-37.9)$ & $23.4(21.9-24.8)$ & $5.6(4.8-6.4)$ \\
\hline Utah & 10,532 & $0.7(0.4-0.9)$ & $4.8(4.3-5.4)$ & $17.5(16.6-18.5)$ & $33.7(32.5-34.8)$ & $32.0(30.9-33.1)$ & $11.3(10.6-12.0)$ \\
\hline Vermont & 5,406 & $0.8(0.5-1.2)$ & $7.7(6.6-8.8)$ & $22.3(20.7-24.0)$ & $35.2(33.4-37.0)$ & $26.1(24.5-27.7)$ & $7.9(7.0-8.8)$ \\
\hline Virginia & 6,851 & $1.4(1.0-1.8)$ & $8.9(7.9-9.9)$ & $24.7(23.3-26.2)$ & $35.0(33.4-36.6)$ & $23.7(22.4-25.1)$ & $6.2(5.5-7.0)$ \\
\hline Washington & 9,518 & $1.1(0.8-1.4)$ & $7.9(7.0-8.7)$ & $22.3(21.1-23.5)$ & $34.6(33.3-36.0)$ & $26.5(25.3-27.7)$ & $7.5(6.8-8.3)$ \\
\hline West Virginia & 5,106 & $1.9(1.3-2.5)$ & $10.6(9.4-11.8)$ & $25.2(23.7-26.8)$ & $35.5(33.8-37.2)$ & $21.5(20.1-22.9)$ & $5.3(4.5-6.0)$ \\
\hline Wisconsin & 5,259 & $1.3(0.8-1.7)$ & $10.0(8.6-11.5)$ & $25.2(23.3-27.2)$ & $35.3(33.1-37.5)$ & $23.7(21.8-25.6)$ & $4.4(3.6-5.3)$ \\
\hline Wyoming & 5,368 & $1.1(0.6-1.6)$ & $7.7(6.6-8.9)$ & $24.1(22.2-26.0)$ & $33.0(31.1-34.9)$ & $26.4(24.7-28.1)$ & $7.6(6.7-8.6)$ \\
\hline Total U.S. & 395,343 & $1.5(1.4-1.6)$ & $8.7(8.5-8.9)$ & $24.5(24.2-24.8)$ & $35.2(34.9-35.5)$ & $24.0(23.7-24.3)$ & $6.2(6.0-6.3)$ \\
\hline U.S. median & NA & 1.5 & 8.7 & 24.7 & 35.0 & 23.6 & 5.8 \\
\hline
\end{tabular}

Abbreviations: $\mathrm{Cl}$, confidence interval; $\mathrm{NA}$, not applicable.

${ }^{a}$ Age-adjusted to the 2000 projected US population.

${ }^{\mathrm{b}}$ Unweighted sample of respondents. 
Table 3. Examples of Strategies to Support Selected Healthy People 2020 Objectives

\begin{tabular}{|c|c|c|c|c|}
\hline & $\begin{array}{l}\text { Epidemiology and } \\
\text { Surveillance }\end{array}$ & Environmental Approaches & Health System Strategies & Community-Clinical Linkages \\
\hline $\begin{array}{l}\text { Healthy People } 2020 \\
\text { Objective }\end{array}$ & $\begin{array}{l}\text { Collect, analyze, and share } \\
\text { data to help identify and } \\
\text { solve problems, evaluate } \\
\text { public health efforts, and } \\
\text { guide and monitor programs } \\
\text { and interventions, research, } \\
\text { and policies to improve } \\
\text { public health. }\end{array}$ & $\begin{array}{l}\text { Promote health and support } \\
\text { and reinforce healthy } \\
\text { behaviors in schools and } \\
\text { child care settings, work } \\
\text { sites, and communities. }\end{array}$ & $\begin{array}{l}\text { Improve the delivery and use } \\
\text { of clinical and other } \\
\text { preventive services that are } \\
\text { designed to prevent disease } \\
\text { or detect it early, reduce risk } \\
\text { factors, and manage } \\
\text { complications. }\end{array}$ & $\begin{array}{l}\text { Link community and clinical } \\
\text { services to ensure that } \\
\text { people with or at high risk of } \\
\text { chronic diseases have access } \\
\text { to the resources they need to } \\
\text { prevent or manage these } \\
\text { diseases. }\end{array}$ \\
\hline $\begin{array}{l}\text { Tobacco Use-1.1: Reduce } \\
\text { cigarette smoking among } \\
\text { adults }\end{array}$ & $\begin{array}{l}\text { - Conduct routine surveillance } \\
\text { in BRFSS (adults), YRBSS } \\
\text { (adolescents), NYTS (youth), } \\
\text { NATS (adults), and YTS } \\
\text { (youth) (http:// } \\
\text { www.cdc.gov/tobacco/ } \\
\text { data_statistics/index.htm). }\end{array}$ & $\begin{array}{l}\text { - Implement comprehensive } \\
\text { tobacco control programs } \\
\text { (19). } \\
\text { - Support increases in the } \\
\text { price of tobacco products } \\
\text { (19). } \\
\text { - Conduct mass-reach } \\
\text { tobacco counter-marketing } \\
\text { campaigns (19). } \\
\text { - Support tobacco-free } \\
\text { policies in schools, work } \\
\text { sites, public places, } \\
\text { multiunit housing, and } \\
\text { health care settings } \\
\text { (www.thecommunityguide.or } \\
\text { g/tobacco). } \\
\text { - Support community } \\
\text { mobilization with additional } \\
\text { interventions to restrict } \\
\text { minors' access to tobacco } \\
\text { products (19). } \\
\text { - Support state quitline } \\
\text { capacity (19). }\end{array}$ & $\begin{array}{l}\text { - Expand insurance coverage } \\
\text { so that all evidence-based } \\
\text { cessation treatments are } \\
\text { covered with no barriers to } \\
\text { accessing coverage (19). } \\
\text { - Inform tobacco users and } \\
\text { their health care providers } \\
\text { of their comprehensive } \\
\text { cessation treatment } \\
\text { insurance benefits (19). } \\
\text { - Promote health systems } \\
\text { changes including electronic } \\
\text { health records with provider } \\
\text { reminder systems that } \\
\text { integrate tobacco screening } \\
\text { and interventions into } \\
\text { routine clinical care (19). } \\
\text { - Promote screening for } \\
\text { tobacco use and tobacco } \\
\text { cessation treatments } \\
\text { (counseling and medication) } \\
\text { (19). }\end{array}$ & $\begin{array}{l}\text { - Link health care systems } \\
\text { with tobacco quitlines and } \\
\text { other community-based } \\
\text { cessation programs in the } \\
\text { state through electronic } \\
\text { health records (19). } \\
\text { - Promote tobacco cessation } \\
\text { in chronic disease self- } \\
\text { management programs } \\
\text { (19). }\end{array}$ \\
\hline $\begin{array}{l}\text { Physical Activity- } 2.1: \text { Increase } \\
\text { the proportion of adults } \\
\text { engaged in aerobic physical } \\
\text { activity of at least a moderate } \\
\text { intensity for at least } 150 \text { min/ } \\
\text { week or } 75 \text { min/week of } \\
\text { vigorous intensity, or an } \\
\text { equivalent combination }\end{array}$ & $\begin{array}{l}\text { - Conduct routine surveillance } \\
\text { in BRFSS (adults) and } \\
\text { YRBSS (adolescents); } \\
\text { SHPPS and Profiles } \\
\text { (www.cdc.gov/healthyyouth/ } \\
\text { data/index.htm). }\end{array}$ & $\begin{array}{l}\text { - Promote adoption of } \\
\text { physical education/physical } \\
\text { activity in schools (20). } \\
\text { - Promote adoption of } \\
\text { physical activity in child care } \\
\text { programs and work sites } \\
\text { (21). } \\
\text { - Promote physical activity } \\
\text { access and outreach (20). } \\
\text { - Design streets and } \\
\text { communities for safe } \\
\text { physical activity (20). }\end{array}$ & $\begin{array}{l}\text { - Promote physical activity as } \\
\text { a vital sign } \\
\text { (www.uspreventiveservicest } \\
\text { askforce.org/Page/ } \\
\text { Document/ } \\
\text { RecommendationStatement } \\
\text { Final/healthy-diet-and- } \\
\text { physical-activity-counseling- } \\
\text { adults-with-high-risk-of-cvd). }\end{array}$ & $\begin{array}{l}\text { Promote physical activity in } \\
\text { chronic disease self- } \\
\text { management programs } \\
\text { (22). }\end{array}$ \\
\hline $\begin{array}{l}\text { Substance Abuse-15: Reduce } \\
\text { the proportion of adults who } \\
\text { drank excessively in the } \\
\text { previous } 30 \text { days }\end{array}$ & $\begin{array}{l}\text { - Conduct routine surveillance } \\
\text { in BRFSS (adults) and } \\
\text { YRBSS (adolescents). }\end{array}$ & $\begin{array}{l}\text { - Support Community } \\
\text { Guide-recommended } \\
\text { strategies (23), such as } \\
\text { alcohol-pricing strategies, } \\
\text { regulating alcohol density, }\end{array}$ & $\begin{array}{l}\text { - Promote alcohol screening } \\
\text { and brief interventions for } \\
\text { adults during routine } \\
\text { medical visits (24). }\end{array}$ & $\begin{array}{l}\text { - Promote adherence to the } \\
\text { Dietary Guidelines on } \\
\text { alcohol in chronic disease } \\
\text { self-management programs } \\
\text { (12). }\end{array}$ \\
\hline
\end{tabular}

Abbreviations: BRFSS, Behavioral Risk Factor Surveillance System; YRBSS, Youth Risk Behavior Surveillance System; NYTS, National Youth Tobacco Survey; NATS, National Adult Tobacco Survey; YTS, Youth Tobacco Survey; SHPPS, School Health Policies and Practices Study.

${ }^{a}$ STOP-BANG sleep apnea questionnaire. STOP includes the following questions: 1) Do you SNORE loudly? 2) Do you often feel TIRED, fatigued, or sleepy during daytime? 3) Has anyone OBSERVED you stop breathing during your sleep? 4) Do you have or are you being treated for high blood PRESSURE? BANG includes the following questions: 1) BMI more than $35 \mathrm{~kg} / \mathrm{m}^{2}$ ? 2) AGE over 50 years old? 3) NECK circumference greater than 16 inches (40 cm)? 4) GENDER is male? 
(continued)

Table 3. Examples of Strategies to Support Selected Healthy People 2020 Objectives

\begin{tabular}{|c|c|c|c|c|}
\hline \multirow{3}{*}{$\begin{array}{l}\text { Healthy People } 2020 \\
\text { Objective }\end{array}$} & $\begin{array}{l}\text { Epidemiology and } \\
\text { Surveillance }\end{array}$ & Environmental Approaches & Health System Strategies & Community-Clinical Linkages \\
\hline & $\begin{array}{l}\text { Collect, analyze, and share } \\
\text { data to help identify and } \\
\text { solve problems, evaluate } \\
\text { public health efforts, and } \\
\text { guide and monitor programs } \\
\text { and interventions, research, } \\
\text { and policies to improve } \\
\text { public health. }\end{array}$ & $\begin{array}{l}\text { Promote health and support } \\
\text { and reinforce healthy } \\
\text { behaviors in schools and } \\
\text { child care settings, work } \\
\text { sites, and communities. }\end{array}$ & $\begin{array}{l}\text { Improve the delivery and use } \\
\text { of clinical and other } \\
\text { preventive services that are } \\
\text { designed to prevent disease } \\
\text { or detect it early, reduce risk } \\
\text { factors, and manage } \\
\text { complications. }\end{array}$ & $\begin{array}{l}\text { Link community and clinical } \\
\text { services to ensure that } \\
\text { people with or at high risk of } \\
\text { chronic diseases have access } \\
\text { to the resources they need to } \\
\text { prevent or manage these } \\
\text { diseases. }\end{array}$ \\
\hline & & $\begin{array}{l}\text { dram shop liability, and } \\
\text { preventing illegal sales. }\end{array}$ & & \\
\hline $\begin{array}{l}\text { Nutrition and Weight Status-8: } \\
\text { Increase the proportion of } \\
\text { adults who are at a healthy } \\
\text { weight }\left(18.5-24.9 \mathrm{~kg} / \mathrm{m}^{2}\right)\end{array}$ & $\begin{array}{l}\text { - Conduct routine surveillance } \\
\text { in BRFSS (adults) and } \\
\text { YRBSS (adolescents). }\end{array}$ & $\begin{array}{l}\text { - Promote adoption of food } \\
\text { service guidelines/nutrition } \\
\text { standards (including } \\
\text { competitive foods) in } \\
\text { schools, childcare programs, } \\
\text { and work sites (20,21), } \\
\text { including cafeterias, } \\
\text { vending, and snack bars. } \\
\text { - Promote policies and } \\
\text { programs that expand } \\
\text { access to healthy food and } \\
\text { beverages in community } \\
\text { settings, including food } \\
\text { retails, farmers markets, } \\
\text { and restaurants }(20) .\end{array}$ & $\begin{array}{l}\text { - Promote a brief dietary } \\
\text { assessment as part of } \\
\text { annual examination. } \\
\text { - Promote screening to } \\
\text { measure the body mass } \\
\text { index of patients during } \\
\text { medical visits } \\
\text { (www.uspreventiveservicest } \\
\text { askforce.org/Page/ } \\
\text { Document/ } \\
\text { UpdateSummaryFinal/ } \\
\text { obesity-in-adults-screening- } \\
\text { and-management). }\end{array}$ & $\begin{array}{l}\text { Promote physical activity, } \\
\text { nutrition, and weight loss in } \\
\text { chronic disease self- } \\
\text { management programs. }\end{array}$ \\
\hline $\begin{array}{l}\text { Sleep Health-4: Increase the } \\
\text { proportion of adults who get } \\
\text { sufficient sleep }\end{array}$ & $\begin{array}{l}\text { - Conduct routine surveillance } \\
\text { in BRFSS (adults) and } \\
\text { YRBSS (adolescents). } \\
\text { - Conduct routine surveillance } \\
\text { of school start times in } \\
\text { school health profiles. }\end{array}$ & $\begin{array}{l}\text { - Promote later school start } \\
\text { policies for adolescents } \\
(25-27) \text {. } \\
\text { - Promote healthy work shift } \\
\text { schedules }(27,28) \text {. }\end{array}$ & $\begin{array}{l}\text { - Promote sleep health } \\
\text { screening and referrals to } \\
\text { sleep specialists during } \\
\text { medical visits } \\
\left(\text { STOP-BANG }{ }^{a}\right)(27,29) \text {. }\end{array}$ & $\begin{array}{l}\text { Promote sleep health } \\
\text { awareness in chronic } \\
\text { disease self-management } \\
\text { programs. }\end{array}$ \\
\hline
\end{tabular}

Abbreviations: BRFSS, Behavioral Risk Factor Surveillance System; YRBSS, Youth Risk Behavior Surveillance System; NYTS, National Youth Tobacco Survey; NATS, National Adult Tobacco Survey; YTS, Youth Tobacco Survey; SHPPS, School Health Policies and Practices Study.

${ }^{a}$ STOP-BANG sleep apnea questionnaire. STOP includes the following questions: 1) Do you SNORE loudly? 2) Do you often feel TIRED, fatigued, or sleepy during daytime? 3) Has anyone OBSERVED you stop breathing during your sleep? 4) Do you have or are you being treated for high blood PRESSURE? BANG includes the following questions: 1) BMI more than $35 \mathrm{~kg} / \mathrm{m}^{2}$ ? 2) AGE over 50 years old? 3) NECK circumference greater than 16 inches (40 $\mathrm{cm}$ )? 4 ) GENDER is male?

The opinions expressed by authors contributing to this journal do not necessarily reflect the opinions of the U.S. Department of Health and Human Services, the Public Health Service, the Centers for Disease Control and Prevention, or the authors' affiliated institutions. 